\title{
Peer review cuts power of Italy's 'barons'
}

[MILAN] A new system for distributing national research funds to Italian universities appears to be working. Its first round of grants has been highly selective - resulting in many researchers experiencing their firstever grant rejection - and has successfully encouraged greater collaboration between universities.

As a result, the government has increased the budget of the board that distributes the funds by more than 50 per cent this year. Part of this new money has been transferred from the funds of the National Research Council (CNR), whose role as a university grant agency the government wants to eliminate (seebelow).

Last year, the government abolished 14 discipline-orientated committees, each directly elected by the academic community, which had been responsible for allocating national university grants. It replaced them with a board of five individuals, selected by the research minister Luigi Berlinguer (see Nature 387,$538 ; 1997)$.

Under the new system, individuals may not apply for new grants. Instead, applications can be made only to extend, through collaboration with other researchers, projects already being financed from other sources, such as the European Commission, and must be submitted by universities.

Successful bids involving collaboration with other researchers within the same university receive an extra 40 per cent on top of their original funding, while those between universities receive an extra 60 per cent. In February, the board approved only onequarter of the applications it had received; 95 per cent of the approved grants were for inter-university collaborations.

The new system, based on independent peer review, is entirely electronic. A database of referees, now being extended to include foreign referees, and available for inspection on the Internet, includes an application form and updated information about the number of applications received.

The two members of the board who share responsibility for all the natural sciences, from agriculture to particle physics (social sciences, humanities and law are handled by the other three members), say they were initially concerned that five was too small a number.

Despite publishing referees' names, the system has been accused by some of lack of transparency. This is because board members have occasionally had to call on unnamed experts to help to select referees.

\section{Grants lure young researchers back home}

[MILAN] One of Italy's largest

research charities, the Italian Association for Cancer Research (ARC), has become the first funding body to offer start-up grants to allow scientists who have worked abroad to return to Italy to take up a research career.

The grants cover salary costs for up to five years, and an additional sum of about IL100 million (US $\$ 50,000)$ a year for direct research costs. ARC's director, Giuseppe Della Porta, says the start-up grants are essential to stop Italy from losing its best young researchers.

One of the new grantholders, Brambilla Riccardo, 35 , a molecular biologist working at DIBIT, the research department of the San Rafaele hospital in Milan, says it would have been difficult for him to come back to Italy without the grant.

"Recruitment policy in Italy, which depends heavily on personal contacts, strongly selects against researchers who go abroad," says Riccardo, who previously worked at the European Molecular Biology Laboratory in Heidelberg, Germany.

In addition to its normal investigator grants, the ARC is offering coordinated grants to consortia of up to six different research groups in defined priority areas. In a bid to bypass the insularity of the Italian academic system, it has also changed its grant selection method.

All information is now provided in English, and applications must be submitted in English. The association's 12 study sections make a preliminary selection of the applications, which are then sent to referees, at least one of whom must be foreign.

Introducing similar reforms at Italy's National Research Council (CNR) has proved more difficult. The government wants to break up the CNR's disciplineorientated committees (as it did the university committees; see above), which had previously allocated research grants, because of their apparent unwillingness to concentrate funding on the best research projects.

It wants the committees to be absorbed into a government-level 'scientific parliament', with purely advisory powers, and to strip the CNR of its responsibilities as a grants agency, partly because it wants a single grant allocation system.

But the CNR has resisted these changes, delaying their implementation.

A new proposal, which would also explain how the scientific parliament would work in practice, is expected to come from the government within the next couple of months.
But the board came to agree with Berlinguer that the new structure is the best way to ensure that the tradition of personal contacts is eliminated. The member responsible for biology and medicine is Jacopo Meldolesi, a cell biologist and director of DIBIT, the research institute of the San Rafaele hospital in Milan. Meldolesi says he was immediately aware of intense pressure to return to the old system, particularly from the powerful academic 'barons' whose applications were rejected. Others criticized the abandonment of a 'democratic' approach to selecting grant review committees.

But Meldolesi says this sort of democracy is not suitable for science. "After all, the first violin in the national orchestra is not chosen by voting: people vote for the most popular, not the most competent." He is aware of his unpopularity in university circles. Despite a strong international reputation as a scientist, he has never served on a grant committee in Italy, and has long been an outspoken critic of a system favouring 'friendships' over scientific excellence. Like other board members, he was chosen by the ministry because he was not part of any university clique.

Antonio Contestabile, professor of neurobiology at the University of Bologna, says one weakness of the new system is that the whole academic community is fighting for a single pot of money that had previously been clearly divided between disciplines.

"This gives enormous space for conflicts of interest, cross-refereeing and manipulation of the final results by the still flourishing academic mafia," he says. "It will take years to reach international standard because we do not have a culture of critical refereeing."

But Alessandro Finazzi Agró, a biochemist and rector of Tor Vegata University in Rome, sees three positive effects of the system. First, approved projects received an average of 80 per cent of the money requested, compared to around 10 per cent under the old system. Second, because of this level of funding, the board will be able to evaluate the results of the grants. And third, he says, universities have been more careful about which projects they finance with their own funds, in order to attract as much extra money as possible from the ministry.

"Of course, in the first round of financing, big slices of Italian research were left out," says Agró. "But now there is some experience with the new system they will have more chance in the next round."

Carlo Calandra, director of the National Institute of Material Sciences, and chairman of the new board, says that the power of the 'academic mafia' will be further weakened by the rule that all applications must be submitted in English as well as Italian, so that foreign referees can be used.

Alison Abbott 